\title{
Inverse Regulation of Early and Late Chondrogenic Differentiation by Oxygen Tension Provides Cues for Stem Cell-Based Cartilage Tissue Engineering
}

\author{
Sophie Portron ${ }^{a, b}$ Vincent Hivernaud ${ }^{a, b}$ Christophe Merceron ${ }^{a, b}$ \\ Julie Lesoeur ${ }^{a, b}$ Martial Masson ${ }^{a, b}$ Olivier Gauthier ${ }^{a, b, c} \quad$ Claire Vinatiera,b $^{a, b}$ \\ Laurent Beck ${ }^{a, b}$ Jérôme Guicheux ${ }^{a, b, d}$
}

aNSERM (Institut National de la Santé et de la Recherche Médicale), UMRS 791, Center for osteoarticular and dental tissue engineering, Group STEP "Skeletal Tissue Engineering and Physiopathology", Nantes Cedex 1, 'University of Nantes, UFR Odontology, Nantes Cedex 1'Center for Preclinical Research and Investigation of the ONIRIS Nantes-Atlantic College of Veterinary Medicine, Food Science and Engineering (CRIP), Nantes Cedex 3, ${ }^{\mathrm{C}} \mathrm{CHU}$ Nantes, Pole hospitalo-universitaire 4 OTONN, Nantes, France

\section{Key Words}

Chondrogenesis $\bullet$ Oxygen tension $•$ Cartilage tissue engineering $\bullet$ Stromal cells $\bullet$ Hypertrophy - HIF $\alpha$

\begin{abstract}
Background/Aims: Multipotent stem/stromal cells (MSC) are considered promising for cartilage tissue engineering. However, chondrogenic differentiation of MSC can ultimately lead to the formation of hypertrophic chondrocytes responsible for the calcification of cartilage. To prevent the production of this calcified matrix at the articular site, the late hypertrophic differentiation of MSCs must be carefully controlled. Given that articular cartilage is avascular, we hypothesized that in addition to its stimulatory role in the early differentiation of chondrogenic cells, hypoxia may prevent their late hypertrophic conversion. Methods: Early and late chondrogenic differentiation were evaluated using human adipose MSC and murine ATDC5 cells cultured under either normoxic $\left(21 \% \mathrm{O}_{2}\right)$ or hypoxic $\left(5 \% \mathrm{O}_{2}\right)$ conditions. To investigate the effect of hypoxia on late chondrogenic differentiation, the transcriptional activity of hypoxia-inducible factor-1alpha (HIF-1 $\alpha$ ) and HIF-2 $\alpha$ were evaluated using the NoShift DNA-binding assay and through modulation of their activity (chemical inhibitor, RNA interference). Results: Our data demonstrate that low oxygen tension not only stimulates the early chondrogenic commitment of two complementary models of chondrogenic cells, but also inhibits their hypertrophic differentiation. Conclusion: These results suggest that hypoxia can be used as an instrumental tool to prevent the formation of a calcified matrix in MSCbased cartilage tissue engineering.

Copyright @ 2015 S. Karger AG, Basel

Jérôme Guicheux

INSERM UMRS 791, Center for osteoarticular and dental tissue engineering 1 Place Alexis Ricordeau, 44042 Nantes Cedex 1 (France)

Tel. +33 (0)240412919, Fax +33 (0)240083712, E-Mail jerome.guicheux@inserm.fr
\end{abstract}

KARGER 125 


\section{Introduction}

Hyaline articular cartilage can become damaged during aging, trauma, and inflammatory or degenerative diseases, which often results in degradation of the extracellular matrix and, ultimately, in the loss of joint function. To address this clinical issue, cell-based reparative strategies using autologous chondrocytes have been proposed and have already shown shortand mid-term promising results [1]. However, this procedure is accompanied by donor site morbidity. Furthermore, the limited number of chondrocytes harvested requires the use of in vitro cell expansion, which is associated with a risk of cell dedifferentiation. Consequently, therapeutic strategies using implanted autologous chondrocytes have rarely resulted in a complete and stable regeneration of hyaline cartilage. Indeed, damaged cartilage repair remains a clinical challenge, recently prompting the development of regenerative strategies based on the use of mesenchymal stromal cells as an alternative to autologous chondrocytes, as well as the development of bio-inspired smart biomaterials [2, 3].

Preclinical and clinical studies have demonstrated the potential of mesenchymal stem/ stromal cells (MSC) in repairing articular cartilage defects [for a review see [4, 5]]. These studies have also highlighted several key challenges for this treatment, such as the quality and durability of the newly formed tissue, its effective integration with the surrounding host tissue, and the control of the chondrogenic differentiation towards a stable, nonhypertrophic phenotype [6]. Indeed, it is well known that MSC committed to chondrogenic differentiation can recapitulate the endochondral ossification process during the transition from the early commitment to the late hypertrophic phase [7]. This late hypertrophic conversion initiates the formation of a mineralized cartilaginous matrix that is ultimately converted into bone [8]. Several studies have reported that in vitro chondrogenicallydifferentiated bone marrow (BM)-derived MSC express several hypertrophy-related genes, such as matrix metalloproteinase 13 (MMP-13) and type X collagen [9-15]. Consistently, this in vitro late hypertrophic differentiation has been reported to lead to the unwanted formation of a calcified matrix when human BM-MSC are subsequently implanted in the subcutis of nude mice $[16,17]$. Therefore, one of the major challenges in MSC-based cartilage tissue engineering is the preservation of the early chondrogenic differentiation to promote hyaline-like tissue repair and prevention of their terminal hypertrophic differentiation.

Since the physiological oxygen tension experienced by articular chondrocytes ranges from 2-7\% [18-20], the use of low oxygen tension to finely tune the chondrogenic phenotype of BM-MSC in vitro [21,22] has been considered with interest. Previous studies have reported that hypoxic conditions could enhance the chondrogenic differentiation of BM-MSC in the presence of an inductive medium [23] while simultaneously impeding their hypertrophic differentiation $[24,25]$.

However, the use of bone marrow suffers from certain limitations related to its painful harvest and the limited amount of collectable MSC. In light of these limitations, adipose tissue has also been considered as an alternative source of MSC. Adipose tissue is easily obtained through non-invasive liposuction and has a larger number of MSC than bone marrow [26-28]. Despite a large body of evidence indicating that adipose stem/stromal cells (ASC) can undergo early chondrogenic differentiation in vitro, their hypertrophic conversion is still largely unknown [29-31]. In addition, while the impact of low oxygen tension on early chondrogenic commitment has been studied [22,32], little is known about its effect on in vitro hypertrophic differentiation, despite being of particular interest for cartilage regenerative medicine.

The main objective of this study was to determine whether low oxygen tension could differentially influence early chondrogenesis and late hypertrophic conversion of human ASC. To confirm the data obtained in human ASC and to further analyze the cellular mechanisms underlying the effects of a low oxygen tension, we were also interested in determining whether hypoxia could influence early and late chondrogenic differentiation in a murine carcinoma-derived chondroprogenitor cell line (ATDC5). Finally, the role of hypoxia inducible factor- $1 \alpha$ (HIF-1 $\alpha)$ and HIF- $2 \alpha$ transcription factors were investigated to ascertain whether 
Portron et al.: $\mathrm{O}_{2}$ Tension Regulates Early and Late Chondrogenesis

the low oxygen tension effects were associated with transcriptional changes. Towards this end, two complementary approaches were used to inhibit HIF- $1 \alpha$ and HIF- $2 \alpha$ function: (i) prevention of their cytoplasmic stabilization using a chemical inhibitor, cadmium chloride $\left(\mathrm{CdCl}_{2}\right)$ and (ii) knocking-down their mRNA expression with small hairpin RNA.

\section{Materials and Methods}

\section{Materials}

Cell culture plastic wares were purchased from Corning-Costar BV Life Sciences (Schipol-Rijk, The Netherlands). Hank's Balanced Sodium Salt (HBSS), Dulbecco's Modified Eagle's Medium (DMEM) - high glucose ( $4.5 \mathrm{~g} / \mathrm{L})$, Minimum Essential Medium $\alpha$, Ham's F12 Nutrient Mixture, phosphate-buffered saline (PBS), penicillin/streptomycin, trypsin/ethylenediaminetetraacetic acid (EDTA) $(0.05 \% / 0.53 \mathrm{mM})$, and the SuperScript III kit were obtained from Invitrogen Corporation (Paisley, UK). Crude collagenase type I A, red blood cell lysis buffer, trypan blue, sodium L-ascorbate, insulin-transferrin-sodium selenite media supplement, dexamethasone, Alcian Blue stain, Alizarin Red S stain, cadmium chloride $\left(\mathrm{CdCl}_{2}\right)$, and guanidine were purchased from Sigma-Aldrich (St. Louis, MO). Brilliant SYBR Green Master Mix was obtained from Stratagene Europe (Amsterdam Zuidoost, The Netherlands). PCR primers were synthesized by MWG Biotech (Ebersberg, Germany). Fetal calf serum (FCS) was purchased from Dominique Dutscher (Brumath, France). The protein content was determined using the Pierce Coomassie Plus assay (Rockford, IL, USA). An enzyme-linked immunosorbent assay (ELISA) kit for MMP13 was obtained from Uscn Life Science Inc, Euromedex (Strasbourg, France). A HIF- $\alpha$ NoShift assay was obtained from Cayman, Bertin Pharma (Montigny, France). Transforming growth factor $\beta 1$ (TGF- $\beta 1$ ) was purchased from PeproTech Inc. (London, UK). NucleoSpin ${ }^{\circledR}$ RNA II was obtained from Macherey-Nagel (Hoerdt, France). pGeneClip vectors carrying shRNA sequences targeting murine hif-1a or endothelial Per-ARNT-Sim domain protein-1 (epas1) mRNA or a scramble sequence were purchased from SA Bioscience (Courtaboeuf, France). Lentiviral pSicoR-GFP vectors were purchased from Addgene (Cambridge, MA, USA). Restriction enzymes were purchased from New England Biolabs (Evry, France). All other chemicals were obtained from standard laboratory suppliers and were of the highest purity available.

\section{Methods}

Lentiviral pSicoR-shRNA vector construction and lentivirus production. The expression of hif1a and epas1 mRNA, coding for HIF-1 $\alpha$ and HIF-2 $\alpha$, respectively, were knocked down using small hairpin RNA (shRNA). Synthetic shRNA sequences targeting murine hif1a or epas1 mRNA or a synthetic scrambled shRNA (non-targeting) were isolated from a commercially available pGeneclip vector using two restrictions enzymes: BamH1 and Not1. The BamH1/Not1 fragments contained shHIF- $1 \alpha$, shHIF- $2 \alpha$, and shscramble sequences under the control of a U1 promoter. These fragments were cloned into the Xba1/Not1 site of the lentiviral vector pSicoR-GFP with an adaptor sequence (5'-CTAGACACGTGG-3') to anneal the BamH1 and Xba1 extremities. The lentiviral particles carrying pSicoR-shHIF-1 $\alpha$, pSicoR-shHIF- $2 \alpha$, and pSicoRshscramble vectors were produced using the virology platform INSERM-U1085 (Bordeaux, France). Briefly, HEK293T cells were plated onto L-polylysine-coated $10 \mathrm{~cm}$ dishes and transfected when the cells were at $50-80 \%$ confluency with $12 \mu \mathrm{g}$ of the lentiviral pSicoR-shRNA construct, $10 \mu \mathrm{g}$ of pPAX2, and $4 \mu \mathrm{g}$ of pVSV-G using the calcium phosphate precipitation method. The virus-containing supernatant was collected $48 \mathrm{~h}$ later, centrifuged for $4 \mathrm{~h}$ at $20,000 \times \mathrm{g}$, aliquoted, and stored at $-80^{\circ} \mathrm{C}$. We determined the titer of each viral supernatant using transduction of serial dilutions of the virus into HEK293T cells and assessing the enhanced green fluorescent protein expression using flow cytometry as previously described [33].

Isolation, expansion, chondrogenic differentiation and hypoxic culture of human ASC. Human ASC were obtained from 3 patients undergoing liposuction after receiving their written consent. All protocols were approved by the local ethics committee. Briefly and as previously described [32], human lipoaspirates were washed extensively with HBSS and treated with collagenase type IA (0.025\%) in HBSS for $1 \mathrm{~h}$ at $37^{\circ} \mathrm{C}$ under gentle agitation. The collagenase was inactivated through addition of an equal volume of DMEM containing $1 \%$ penicillin/streptomycin and 10\% FCS (control medium). The digested product was then centrifuged at $250 \times \mathrm{g}$ for $5 \mathrm{~min}$ to separate the adipocytes from the stromal cells. The supernatant was removed, the cells were resuspended in the control medium and the suspension was filtered through a $70 \mu$ m nylon mesh 
filter. The filtrate was centrifuged and the cells were resuspended in red blood cell lysis buffer. Addition of the control medium halted the lysis reaction. The suspension was centrifuged, and the cells were counted using trypan blue. The cells were resuspended in control medium and plated at a density of $5 \times 10^{4}$ cells/ $\mathrm{cm} 2$. The medium was replaced $24 \mathrm{~h}$ after seeding to remove non-adherent cells. To prevent spontaneous differentiation, primary cultures of ASC were grown to $80-90 \%$ confluency and then detached from the cell culture flask using trypsin-EDTA. All cultures were incubated at $37^{\circ} \mathrm{C}$ and $5 \% \mathrm{CO}$, and the medium was changed every two to three days.

Five hundred thousand ASC (passage 3) were placed into a $15 \mathrm{~mL}$ polypropylene tube containing $1 \mathrm{~mL}$ of control medium. The cells were centrifuged for $5 \mathrm{~min}$ at $250 \times \mathrm{g}$. The tubes were fitted with vented caps to permit gas exchange, and the cell pellets were maintained at $37^{\circ} \mathrm{C}$ in a humidified atmosphere containing $5 \% \mathrm{CO}_{2}$ and $95 \%$ air. After $24 \mathrm{~h}$, the ASC pellets were divided into three experimental groups.

To characterize the ability of ASC to undergo chondrogenic differentiation and examine the effects of hypoxia on their phenotype, pellets of ASC were cultured under normoxia $\left(21 \% \mathrm{O}_{2}\right)$, either in the presence of control medium (NCT) or chondrogenic medium $(\mathrm{NCH})$, or under hypoxia $\left(5 \% \mathrm{O}_{2}\right)$ in the presence of chondrogenic medium (HCH) for 14, 21, and 28 days. The chondrogenic medium was composed of serumfree DMEM supplemented with 1\% penicillin/streptomycin, $6.25 \mu \mathrm{g} / \mathrm{mL}$ insulin, $6.25 \mu \mathrm{g} / \mathrm{mL}$ transferrin, $6.25 \mathrm{ng} / \mathrm{mL}$ sodium selenite, $50 \mathrm{nM}$ sodium L-ascorbate, $1 \times 10^{-8} \mathrm{M}$ dexamethasone, and $10 \mathrm{ng} / \mathrm{mL}$ TGF- $\beta 1$ as previously described $[32,34]$. The culture medium was changed every $2-3$ days. For the HCH conditions, ASC were cultured as described above and placed at $37^{\circ} \mathrm{C}$ in a humidified atmosphere inside a tri-gas incubator containing $5 \% \mathrm{CO}_{2}, 5 \% \mathrm{O}_{2}$, and $90 \% \mathrm{~N}_{2}$.

ATDC5 cells culture. The ATDC5 cells were routinely cultured in control medium consisting of DMEM/ F12 (1:1) containing 5\% FCS and 1\% penicillin/streptomycin. Cells were passaged once a week using trypsin/EDTA and maintained at $37^{\circ} \mathrm{C}$ in a humidified atmosphere of $5 \% \mathrm{CO}_{2}$ in air. The chondrogenic medium consisted of the growing medium supplemented with $10 \mu \mathrm{g} / \mathrm{mL}$ insulin, $10 \mu \mathrm{g} / \mathrm{mL}$ transferrin, and $10 \mathrm{ng} / \mathrm{mL}$ sodium selenite. ATDC5 cells were counted using trypan blue and cultured at $1.5 \times 10^{4} / \mathrm{cm}^{2}$ in control or chondrogenic medium for two weeks under normoxia $\left(21 \% \mathrm{O}_{2}\right)$ and then for an additional seven days in chondrogenic medium under normoxic or hypoxic $\left(5 \% \mathrm{O}_{2}\right)$ conditions. For the HCH samples, the cells were cultured inside a tri-gas incubator containing $5 \% \mathrm{CO}_{2}, 5 \% \mathrm{O}_{2}$, and $90 \% \mathrm{~N}_{2}$. The medium was changed every 2-3 days.

For the HIF- $1 \alpha$ and HIF-2 $\alpha$ inhibition experiments, ATDC5 cells were cultured under NCH conditions for 14 days and for an additional $24 \mathrm{~h}$ under $\mathrm{HCH}$ conditions or $\mathrm{HCH}$ conditions with $20 \mu \mathrm{M}$ of cadmium chloride $\left(\mathrm{CdCl}_{2}\right)$. The inhibitor concentration was chosen according to the concentrations commonly used in the literature [35]. To specifically achieve HIF-1 $\alpha$ or HIF-2 $\alpha$ loss of function, their mRNA expression was knocked down using shRNA. Towards this end, ATDC5 cells were cultured under NCH conditions for 14 days and then for an additional $24 \mathrm{~h}$ under $\mathrm{HCH}$ conditions or $\mathrm{HCH}$ conditions treated with lentiviral particles carrying the shHIF- $1 \alpha$ or shHIF- $2 \alpha$. Negative controls were performed using the scrambled shRNA.

RNA isolation. Total RNA was extracted from ASC and ATDC5 cells using a Nucleospin ${ }^{\circledR}$ RNA II kit in accordance with the manufacturer's instructions. After DNase digestion, the RNA was quantified using a UV spectrophotometer (Nanodrop ND-1000, Labtech; Palaiseau, France), and the quality was determined with the Agilent Bioanalyser 2100 system (Waldbronn, Germany).

Real-time PCR. One microgram of total RNA was reverse transcribed using the Superscript ${ }^{\circledR}$ III kit. Complementary DNA (CDNA) was amplified in a total volume of $15 \mu \mathrm{L}$ of the PCR reaction mix containing $12.5 \mu \mathrm{L}$ of Brilliant ${ }^{\circledR}$ SYBR $^{\circledR}$ Green Master Mix (1×), $30 \mathrm{nM}$ SYBR green reference dye, and each primer at a concentration of $10 \mu \mathrm{M}$. The sequences of the human and mouse primers are provided in Tables 1 and 2, respectively. Real-time PCR was performed in a MX3000 ${ }^{\circledR}$ real-time PCR system (Stratagene; La Jolla, CA, USA) under the following conditions: $10 \mathrm{~min}$ at $95^{\circ} \mathrm{C}$ and then 40 cycles of $30 \mathrm{~s}$ at $95^{\circ} \mathrm{C}, 1 \mathrm{~min}$ at $60^{\circ} \mathrm{C}$, and $30 \mathrm{~s}$ at $72^{\circ} \mathrm{C}$. The efficiency and specificity of each primer set was confirmed using standard curves of the cycle threshold values vs serial dilutions of total RNA and evaluating the melting profile. Cycle thresholds were normalized to those of $a c t b$ (beta actin) and gusb (beta glucuronidase) for ATDC5 cells and PPIA (peptidylprolyl isomerase A) for ASC mRNA. The results are reported as relative expression levels.

Histological analysis. Three ASC pellets of each culture condition were fixed in $10 \%$ formalin and embedded in paraffin. Paraffin sections ( $5 \mu \mathrm{m}$ thick) were deparaffinized using toluene, rehydrated through a graded series of ethanol, and rinsed in distilled water. Sections were stained with Masson's Trichome and Alcian Blue stains as previously described [32]. Alcian Blue staining revealed the presence of a sulfated 
Portron et al.: $\mathrm{O}_{2}$ Tension Regulates Early and Late Chondrogenesis

Table 1. Sequences of the human primer pairs, gene bank accession numbers used for the real-time PCR analysis, and the size of the PCR products

\begin{tabular}{|c|c|c|c|}
\hline Gene & Gene Bank Accession Number & Sequence & Base Pairs (bp) \\
\hline PPIA & NM_021130.3 & $\begin{array}{l}\text { Fwd 5'-ATGCTGGACCCAACACAAAT-3' } \\
\text { Rev 5'-TCTTTCACTTTGCCAAACACC-3' }\end{array}$ & 97 \\
\hline SOX9 & NM_000346.2 & $\begin{array}{l}\text { Fwd 5'-GTACCCGCACTTGCACAAC-3' } \\
\text { Rev 5'-TCGCTCTCGTTCAGAAGTCTC-3' }\end{array}$ & 72 \\
\hline$A C A N$ & NM_001135.1 & $\begin{array}{l}\text { Fwd 5'-CCTCCCCTTCACGTGTAAAA-3' } \\
\text { Rev 5'-GCTCCGCTTCTGTAGTCTGC-3' }\end{array}$ & 64 \\
\hline COL2A1 & NM_001844 & $\begin{array}{l}\text { Fwd 5'-TGTCAGGGCCAGGATGTC-3' } \\
\text { Rev 5'-ATCATTATACCTCTGCCCATCC-3' }\end{array}$ & 63 \\
\hline COL10A1 & NM_000493.3 & $\begin{array}{l}\text { Fwd 5'-CACCTTCTGCACTGCTCATC-3' } \\
\text { Rev 5'-GGCAGCATATTCTCAGATGGA-3' }\end{array}$ & 104 \\
\hline MMP13 & NM_002427.2 & $\begin{array}{l}\text { Fwd 5'-CCAGTCTCCGAGGAGAAACA-3' } \\
\text { Rev 5'-AAAAACAGCTCCGCATCAAC-3' }\end{array}$ & 85 \\
\hline
\end{tabular}

Table 2. Sequences of the mouse primer pairs, gene bank accession numbers used for the real-time PCR analysis, and the size of the PCR products

\begin{tabular}{|c|c|c|c|}
\hline Gene & Gene Bank Accession Number & Sequence & Base Pairs (bp) \\
\hline$a c t b$ & NM_007393 & $\begin{array}{l}\text { Fwd 5'-AAGGCCAACCGTGAAAAGAT-3' } \\
\text { Rev 5'-GTGGTACGACCAGAGGCATAC-3' }\end{array}$ & 110 \\
\hline gusb & NM_010368.1 & $\begin{array}{l}\text { Fwd 5'-CTCTGGTGGCCTTACCTGAT-3' } \\
\text { Rev5'-CAGTTGTTGTCACCTTCACCTC-3' }\end{array}$ & 73 \\
\hline $\operatorname{sox} 9$ & NM_011448.3 & $\begin{array}{l}\text { Fwd 5'-CAGCAAGACTCTGGGCAAG-3' } \\
\text { Rev 5'-ATCGGGGTGGTCTTTCTTGT-3' }\end{array}$ & 109 \\
\hline acan & NM_007424.2 & $\begin{array}{l}\text { Fwd 5'-GCTGAAGTCCCTGGTCAGC-3' } \\
\text { Rev 5'-GCCTCCTCAAATGTCAGAGAGTA-3' }\end{array}$ & 92 \\
\hline col2a1 & NM_031163.2 & $\begin{array}{l}\text { Fwd 5'-GCGAGCCTGGTGTCTCTG-3' } \\
\text { Rev 5'-GCCTCTTTCCCCAGACTTTC-3' }\end{array}$ & 110 \\
\hline col10a1 & NM_009925 & $\begin{array}{l}\text { Fwd 5'-GCATCTCCCAGCACCAGA-3' } \\
\text { Rev 5'-CCATGAACCAGGGTCAAGAA-3' }\end{array}$ & 85 \\
\hline mmp13 & NM_008607.1 & $\begin{array}{l}\text { Fwd 5'-CAGTCTCCGAGGAGAAACTATGAT-3' } \\
\text { Rev 5'-GGACTTTGTCAAAAAGAGCTCAG-3' }\end{array}$ & 94 \\
\hline hif1a & NM_010431.2 & $\begin{array}{l}\text { Fwd 5'-GCACTAGACAAAGTTCACCTGAGA-3' } \\
\text { Rev 5'-CGCTATCCACATCAAAGCAA-3' }\end{array}$ & 102 \\
\hline epas1 & NM_010137.3 & $\begin{array}{l}\text { Fwd 5'-GACATGAAGTTCACCTACTGTGATG-3' } \\
\text { Rev 5'-GCGCATGGTAGAATTCATAGG-3' }\end{array}$ & 105 \\
\hline
\end{tabular}

glycosaminoglycans (GAG)-containing cartilaginous matrix. Masson's Trichrome stained the collagen fibers in green.

Biochemical analyses. The production of GAG by ATDC5 cells was investigated with Alcian Blue staining as previously described [32]. Briefly, the extracellular matrix was washed with ice-cold PBS and fixed for 20 min in $100 \%$ ethanol. The extracellular matrix was then stained at room temperature with a $0.1 \%$ Alcian Blue solution in $0.1 \mathrm{M} \mathrm{HCl}$. After incubation overnight, the solution was discarded and the extracellular matrix was rinsed with $0.1 \mathrm{M} \mathrm{HCl}$ to eliminate nonspecific staining. Photographs were obtained with a light microscope. The Alcian Blue staining was quantified using a solution of guanidine/ $\mathrm{HCl} 6 \mathrm{M}$. After $8 \mathrm{~h}$, the liquid was harvested and the Alcian Blue optical density was determined on a spectrophotometer using a wavelength of $595 \mathrm{~nm}$.

Calcium deposition in ATDC5 cells culture was detected using Alizarin Red staining as previously described [36]. Briefly, the extracellular matrix was washed with cold PBS and stained with 2\% Alizarin Red solution for $2 \mathrm{~min}$. Stained cells were extensively washed with deionized water to remove any nonspecific staining. Photographs were obtained with a light microscope. Alizarin Red was extracted using a solution of $20 \%$ methanol and $10 \%$ acetic acid in water. After $15 \mathrm{~min}$, the liquid was harvested and the Alizarin Red optical density was determined on a spectrophotometer using a wavelength of $450 \mathrm{~nm}$.

The concentration of MMP13 in the supernatant of ATDC5 and ASC cultures was measured using an ELISA kit in accordance with the manufacturer's instructions.

Nuclear protein extraction. Nuclear protein extraction was performed as previously described [37]. ATDC5 cells were rapidly frozen in liquid nitrogen before lysis at $4^{\circ} \mathrm{C}$. The cells were scraped in low salt buffer: 10 mM 4-2-Hydroxyethyl-piperazine-1-ethanesulfonic acid (HEPES), pH 7.9, 0.1\% Nonidet P-40, 1.5 $\mathrm{mM} \mathrm{MgCl}, 10 \mathrm{mM} \mathrm{KCl}, 1 \mathrm{mM}$ ethylene glycol tetraacetic acid, $1 \mathrm{mM}$ EDTA, $0.5 \mathrm{mM}$ dithiothreitol (DTT), $0.5 \mathrm{mM}$ phenylmethylsulfonyl fluoride (PMSF), $10 \mu \mathrm{g} / \mathrm{mL}$ pepstatin A, $10 \mu \mathrm{g} / \mathrm{mL}$ aprotinin, and $10 \mu \mathrm{g} / \mathrm{mL}$ 
leupeptin. The suspension was incubated on ice for $1 \mathrm{~h}$ with gentle shaking every $15 \mathrm{~min}$ and sedimented with centrifugation $(10,000 \times \mathrm{g})$ for $10 \mathrm{~min}$ at $4^{\circ} \mathrm{C}$. The pellet was resuspended in a high salt buffer $(20 \mathrm{mM}$ HEPES, pH 7.9, 25\% glycerol, 1 mM MgCl 2,420 mM NaCl, 0.2 mM EDTA, 0.5 mM DTT, 0.5 mM PMSF, $10 \mu \mathrm{g} /$ $\mathrm{mL}$ pepstatin $\mathrm{A}, 10 \mu \mathrm{g} / \mathrm{mL}$ aprotinin, and $10 \mu \mathrm{g} / \mathrm{mL}$ leupeptin) and incubated for 1-3 hours with gentle shaking every 15 minutes. The nuclear suspension was centrifuged at $10,000 \times g$ for $10 \mathrm{~min}$ at $4^{\circ} \mathrm{C}$. The supernatants were then collected and stored at $-80^{\circ} \mathrm{C}$. The protein concentration of the nuclear lysates was determined with a Pierce Coomassie Plus protein assay.

NoShift transcription factor assay for HIF-1 $\alpha$ and HIF-2 $\alpha$. The DNA-binding activity of the transcription factors HIF- $1 \alpha$ and HIF- $2 \alpha$ was investigated using an ELISA-based electrophoretic mobility shift assay (EMSA) using the HIF- $\alpha$ NoShift transcription factor assay kit, according to the manufacturer's recommendations.

\section{Statistical analysis}

Each experiment was repeated at least three times with similar results. Results are expressed as the mean \pm standard error of the mean of the triplicate experiments. Means were compared using a oneway analysis of variance followed by a post-hoc test (Fisher's Least Significant Difference) with statistical significance set at $p<0.05$.

\section{Results}

Characterization of the chondrogenic and hypertrophic phenotypes of ASC

Before investigating the effect of hypoxia on chondrogenesis in ASC, we sought to characterize the ability of ASC to undergo chondrogenic differentiation using Alcian Blue and Masson's Trichrome staining. Alcian Blue staining of ASC pellets cultured in the control medium failed to reveal the presence of sulfated GAG within the matrix (Fig. 1A, a-c). By contrast, the chondrogenic medium produced a blue ring at the external zone of the pellet section, as early as day 14, demonstrating the synthesis of sulfated GAG within the matrix (Fig. 1A, d-f). The same pattern was seen for the Masson's Trichrome staining, where the pellets cultured in the control medium (Fig. 1A, g-i) showed no visible staining and the ASC pellets cultured in the chondrogenic medium were positive for Masson's Trichrome staining (Fig. 1A, j-l). Green-stained collagen fibers were mainly detected at the external zone of the pellet section as early as day 21 , whereas collagen fibers were observed within the whole pellet section at day 28 (Fig. 1A, l). To confirm the expression of chondrogenic markers on the mRNA level, SRY (sex determining region Y)-box 9 (SOX9), aggrecan (ACAN), and collagen type 2 alpha1 (COL2A1) were measured using real-time-PCR. Whereas the expression levels of SOX9, ACAN and COL2A1 mRNA did not increase under the NCT conditions, the chondrogenic medium induced a significant time-dependent increase in the expression of SOX9, ACAN, and COL2A1 (Fig. 1B).

To specifically document the terminal chondrogenic differentiation of ASC, the expression levels of COL10A1 and MMP13 mRNA were investigated. Interestingly, in the presence of chondrogenic medium, the expression levels of COL10A1 and MMP13 were temporally and significantly increased at day 14, 21 and 28 (Fig. 1B). Taken together, these data confirm that human ASC are able to undergo both early and late hypertrophic chondrogenic differentiation in the presence of a specific inductive medium.

\section{Effect of hypoxia on the chondrogenic and hypertrophic phenotypes of ASC}

After confirming that human ASC exhibited the main features of early chondrogenic and late hypertrophic phenotypes, we sought to determine the effect of hypoxia on these states. Alcian Blue and Masson's Trichrome staining of ASC pellets cultured for 28 days in chondrogenic medium were positive and of comparable intensity under both normoxic and hypoxic conditions. This suggests that the production of sulfated GAG and collagen fibers were similar in both environments (Fig. 2A). Interestingly, the real-time PCR data indicated that ASC cultured under hypoxic conditions for 28 days exhibited a significant increase in SOX9, ACAN and COL2A1 mRNA expression compared to ASC cultured under 


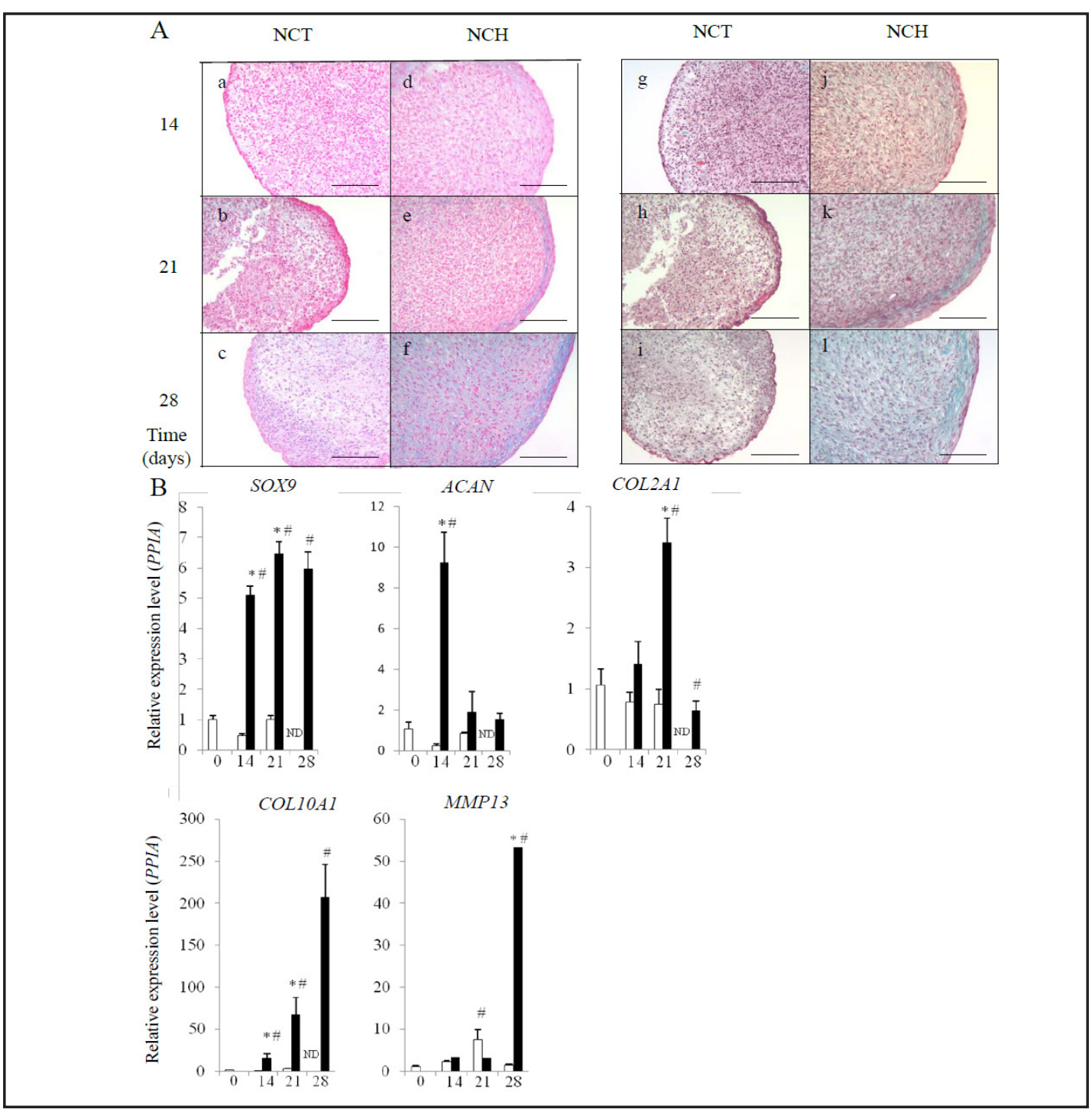

Fig. 1. Characterization of the chondrogenic and hypertrophic phenotypes of ASC. Human ASC were cultured in pellets for 14, 21 and 28 days in the presence of control (NCT / white bars) and chondrogenic medium (NCH / black bars). (A) Histological sections of ASC pellets were stained with Alcian Blue (a-f) or Masson's Trichrome (g-l) stain. Bar: $100 \mu \mathrm{m}$. Original magnification X 200. (B) Expression of the chondrogenic markers SOX9, ACAN and COL2A1 and hypertrophic markers COL1OA1 and MMP13 was investigated using real-time PCR, as described in the materials and methods section. Results are expressed as relative expression levels compared to the control medium at day $0 .{ }^{*} \mathrm{p}<0.05$ compared to the control medium at the same day. $\#$ p < 0.05 compared to the respective control medium at day 0. ND: not detected.

normoxic conditions, showing a 1.7-, 4.5-, and 2.5-fold increase, respectively. There was also a significant decrease, about $50 \%$ and $60 \%$, in the steady state levels of COL10A1 and MMP13 transcripts in the ASC cultured under hypoxic conditions (Fig. 2B). In addition, the relative MMP13 protein concentration was found to be significantly decreased under $\mathrm{HCH}$ conditions compared to NCH conditions (Fig. 2C). Taken together, these data suggest that low oxygen tension not only promotes the expression of early chondrogenic markers in human ASC, but also downregulates the hypertrophic markers.

Characterization of the chondrogenic and hypertrophic phenotypes of ATDC5 cells

To strengthen our hypothesis that low oxygen tension exerts its effects on a broad range of chondrogenic cells, we performed experiments using the murine chondroprogenitor cell KARGER 
A

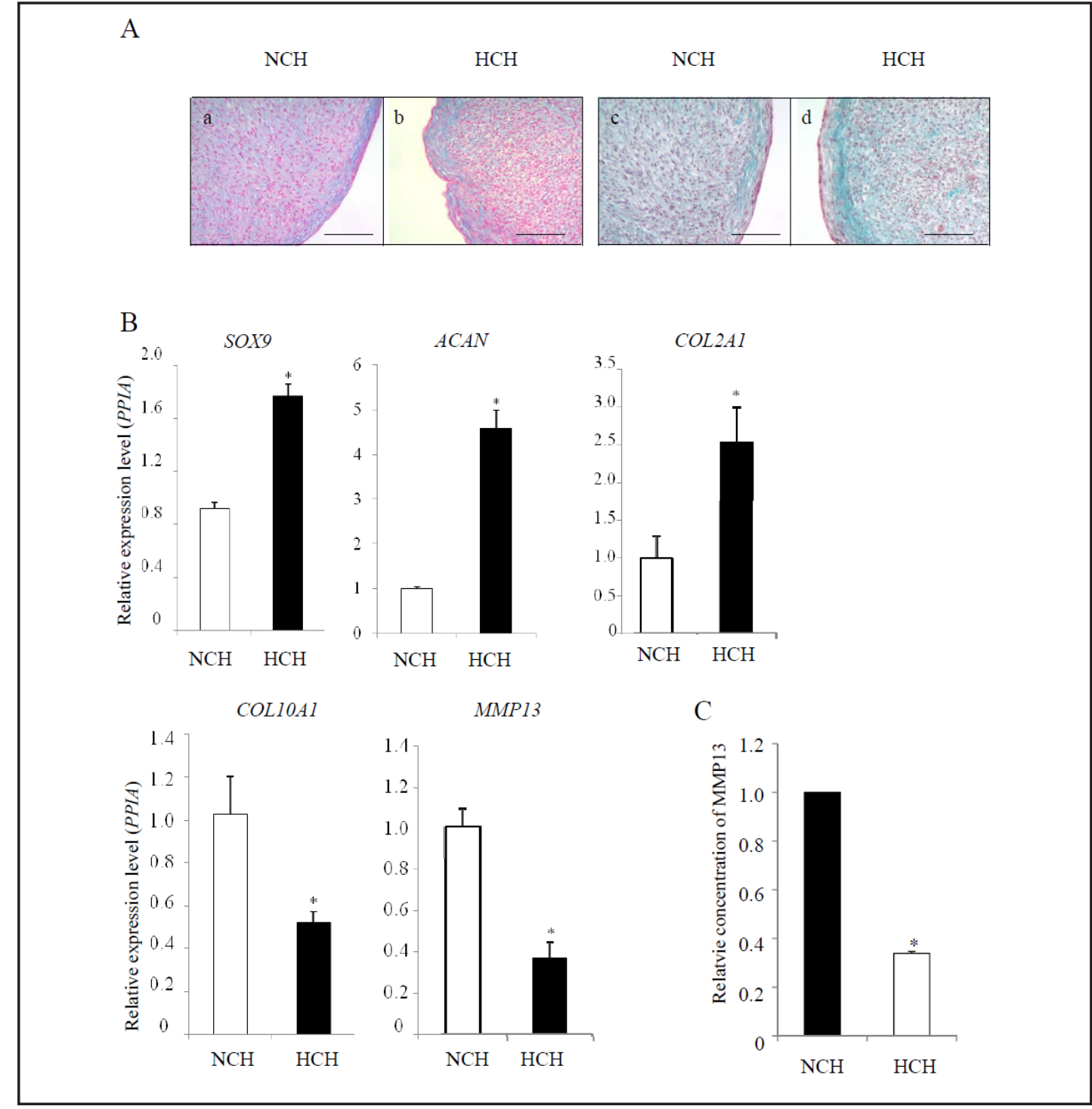

Fig. 2. Effect of hypoxia on the chondrogenic and hypertrophic phenotypes of ASC. Human ASC were cultured in pellets for 28 days in the presence of chondrogenic medium under normoxic (NCH / white bars) or hypoxic (HCH / black bars) conditions. (A) Histological sections were stained with Alcian Blue (a,b) or Masson's Trichrome (c,d) stain. Bar: $100 \mu \mathrm{m}$. Original magnification X 200. (B) Expression of the chondrogenic markers SOX9, ACAN, and COL2A1 and hypertrophic markers COL1OA1 and MMP13 was investigated using real-time PCR, as described in the materials and methods section. Results are expressed as relative expression levels. *p $<0.05$ compared with the NCH conditions. (C) The concentration of MMP13 was measured in the ASC culture supernatant, as described in the materials and methods section. Results are expressed as relative concentrations. ${ }^{*} \mathrm{p}<0.05$ compared with the $\mathrm{NCH}$ conditions.

line, ATDC5 $[38,39]$. These data confirmed that the presence of chondrogenic medium caused ATDC5 cells to form nodular structures as early as day 7 . We also observed that at day 14 and 21, sulfated GAG and calcium deposits increased within the matrix, as evidenced by Alcian Blue and Alizarin Red staining, respectively. These observations correlated well with the quantification of the extracted stains (Fig. 3A and 3B). The real-time PCR data revealed that under NCH conditions, the expression level of sox 9 mRNA markedly increased as early as day 14, whereas those of acan and col2a1 increased at days 14 and 21 (Fig. 3C). 
A

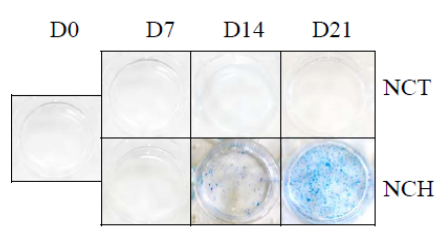

$\mathrm{B}$

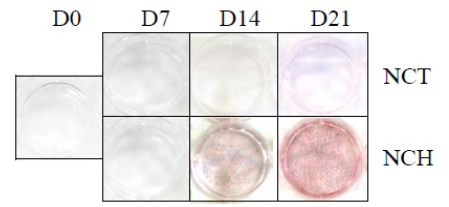

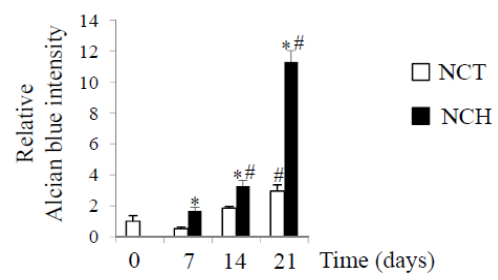

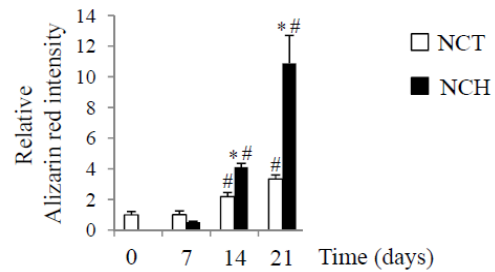

$\mathrm{C}$
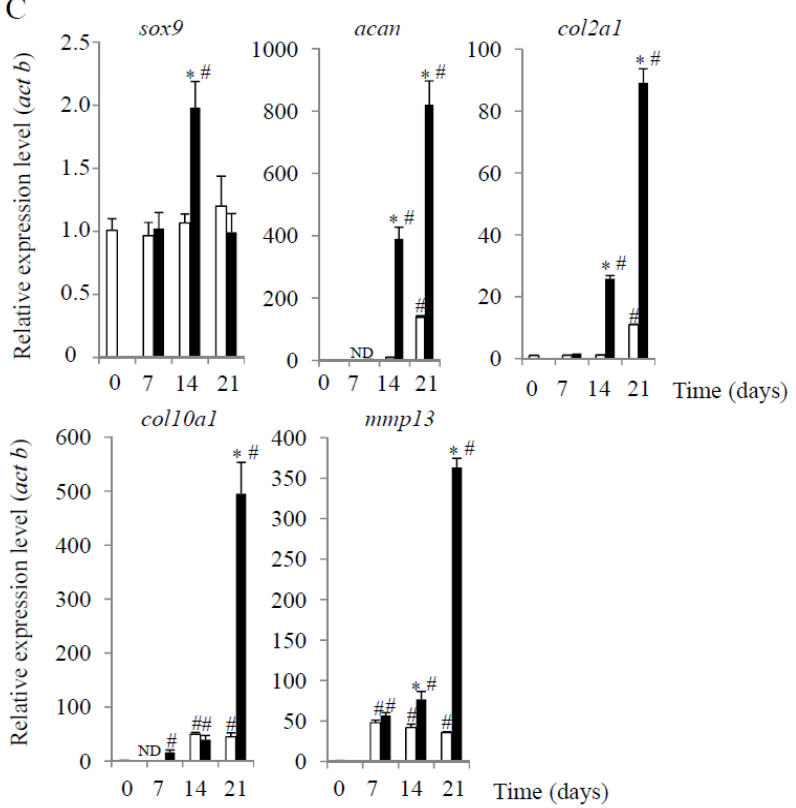

Fig. 3. Characterization of the chondrogenic and hypertrophic phenotypes of ATDC5 cells. ATDC5 cells were cultured for $0,7,14$ and 21 days in the presence of control (NCT / white bars) and chondrogenic medium (NCH / black bars). (A) Sulfated GAG accumulation was revealed with Alcian Blue staining. The staining was extracted and quantified, as described in the materials and methods section. Results are expressed as the relative Alcian Blue content compared to the control medium at day $0 .{ }^{*} \mathrm{p}<0.05$ compared to the control medium at the same day. \#p $<0.05$ compared to the control medium at day 0. (B) Calcium deposition was evaluated with Alizarin Red staining. The staining was then extracted and quantified, as described in the materials and methods section. Results are expressed as the relative Alizarin Red content compared to the control medium at day $0 .{ }^{*} \mathrm{p}<0.05$ compared to the control medium at the same day. $\# \mathrm{p}<0.05$ compared to the control medium at day 0. (C) Expression of the chondrogenic markers sox9, acan, and col2a1 and hypertrophic markers col10a1 and mmp13 was investigated using real-time PCR, as described in the materials and methods section. Results are expressed as the relative expression level compared to the basal level at day 0 . ${ }^{*} p<0.05$ compared to the control medium at the same day. \# $p<0.05$ compared to the control medium at day 0. ND: not detected.

Prior to investigating the effects of low oxygen tension on the hypertrophic phenotype of ATDC5 cells, we first monitored the appearance of hypertrophic differentiation over time. Fig. 3C shows that ATDC5 cells cultured under NCH conditions exhibited a time-dependent, significant increase in the expression levels of col10a1 and mmp13 mRNA. 
Our data confirmed that ATDC5 cells in inductive medium undergo chondrogenic differentiation and express hypertrophic markers in a time-dependent manner. These data suggest that the transition from a chondrogenic to hypertrophic phenotype arises around day 14 of culture.

Effect of hypoxia on the chondrogenic and hypertrophic phenotypes of ATDC5 cells

We sought to address whether a hypoxic environment during days 14-21 of cell culture could influence the chondrogenic and hypertrophic phenotypes of ATDC5 cells. Fig. 4A indicates that ATDC5 cells cultures were positive for Alcian Blue staining (left panel), with no significant difference between the normoxic and hypoxic conditions (right panel). Conversely, calcium deposition evidenced by Alizarin Red staining (Fig. 4B, left panel) and quantification (Fig. 4B, right panel) was significantly decreased when cells were cultured under hypoxic conditions compared to those cultured under normoxic.

Interestingly, while sox 9 , acan and col2a1 transcripts were significantly increased in cells cultured under $\mathrm{HCH}$ conditions for 14 days (1.7-, 8-, and 1.5-fold increases, respectively), the expression levels of col10a1 and mmp13 mRNA were significantly decreased by $50 \%$ and $90 \%$, respectively (Fig. 4C). These data are consistent with the decrease in MMP13 concentration observed when ATDC5 cells were cultured under hypoxic conditions. (Fig. 4D).

Taken together, these data suggest that low oxygen tension not only promotes the expression of early chondrogenic markers in ATDC5 cells, but also downregulates the levels of hypertrophic markers.

Effect of HIF-1 $\alpha$ and HIF-2 $\alpha$ inhibition on the expression of mmp13 $\mathrm{mRNA}$

Given that HIF- $1 \alpha$ and HIF- $2 \alpha$ are the key transcription factors responsible for the cellular effects of hypoxia, we wanted to determine their role in the regulation of hypertrophic markers in ATDC5 cells. To ascertain whether the 5\% oxygen tension used in this study could lead to the stabilization of HIF- $1 \alpha$ and HIF- $2 \alpha$, we measured the DNA-binding activity of these two transcription factors. The NoShift transcription factor assay revealed that HIF$1 \alpha$ and HIF- $2 \alpha$ bound their DNA consensus sequences after $4 \mathrm{~h}$ of culture under hypoxic conditions. Subsequently, the DNA-binding activity of HIF- $1 \alpha$ and HIF- $2 \alpha$ decreased at $8 \mathrm{~h}$ and $12 \mathrm{~h}$ (Fig. 5A). As control, the hypoxia-induced HIF-1 $\alpha$ and HIF-2 $\alpha$ DNA binding was prevented in a competitive assay with a 50 -fold molar excess of Hypoxia Response Element (HRE) oligomers (data not shown).

To determine whether HIF- $1 \alpha$ and/or HIF- $2 \alpha$ may play a role in the effect of hypoxia on the hypertrophic differentiation of ATDC5 cells, $\mathrm{CdCl}_{2}$ was used to prevent their cytoplasmic stabilization. We used this inhibitor for a limited period of time $(24 \mathrm{~h})$ to prevent any negative effects on ATDC5 cells viability. As expected, in ATDC5 cells treated with $\mathrm{CdCl}_{2}$ under $\mathrm{HCH}$ conditions, the DNA-binding activities of both HIF- $1 \alpha$ and HIF- $2 \alpha$ were significantly reduced (Fig. 5B).

We next tested whether $\mathrm{CdCl}_{2}$ treatment could alter the hypertrophic conversion of ATDC5 cells. We measured the expression level of MMP13, the only hypertrophic marker that was sensitive to hypoxia in the short $24 \mathrm{~h}$ time period (data not shown). Interestingly, whereas the expression level of $\mathrm{mmp} 13 \mathrm{mRNA}$ was downregulated under hypoxic conditions, it was not statistically different under normoxic and hypoxic conditions when the cells were treated with $\mathrm{CdCl}_{2}$ (Fig. 5C).

To gain clearer insight into the specific role of HIF- $1 \alpha$ and/or HIF- $2 \alpha$ on the hypoxiamediated inhibition of hypertrophic differentiation of ATDC5 cells, we used a shRNA approach. As depicted in Fig. 5D, in ATDC5 cells infected with lentiviral particles carrying shHIF- $1 \alpha$ or shHIF- $2 \alpha$, the expression level of the target genes was decreased compared with ATDC5 cells infected with lentiviral particles carrying scrambled shRNA. As we previously observed with $\mathrm{CdCl}_{2}$ treatment, the hypoxic inhibition of the expression level of $m m p 13$ mRNA was abolished in the presence of either shHIF-1 $\alpha$ or shHIF-2 $\alpha$ (Fig. 5E). These data suggest that HIF- $1 \alpha$ and HIF- $2 \alpha$ are involved in the regulation of the expression of $m m p 13$ mRNA that occurs under low oxygen tension. 


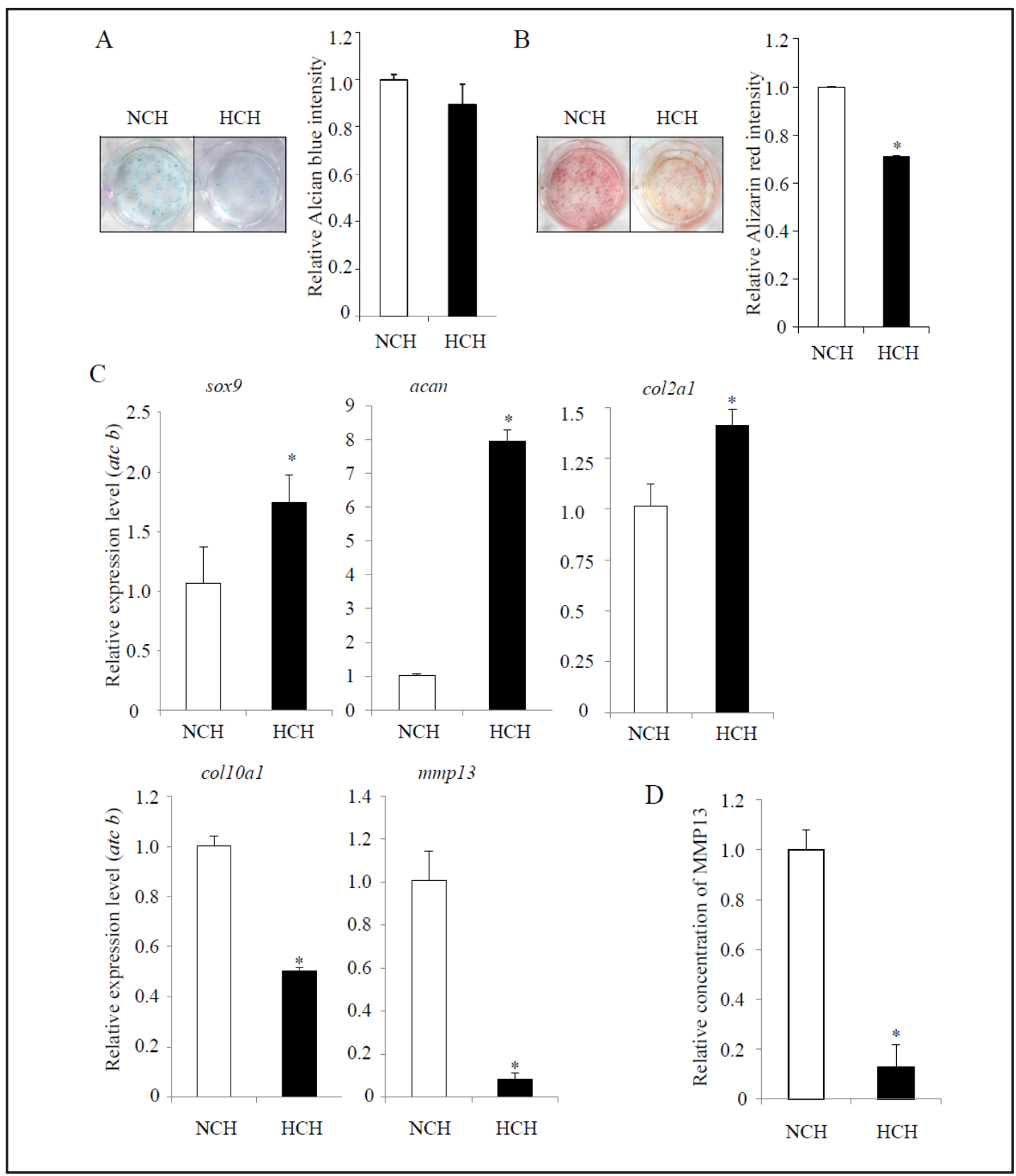

Fig. 4. Effect of hypoxia on the chondrogenic and hypertrophic phenotypes of ATDC5 cells. ATDC5 cells were cultured for 14 days in the presence of chondrogenic medium under normoxic conditions and then cultured for a 7 day period of time, either under normoxic ( $\mathrm{NCH} /$ white bars) or hypoxic (HCH / black bars) conditions. (A) Sulfated GAG accumulation was revealed by Alcian Blue staining. The staining was extracted and quantified, as described in the materials and methods section. Results are expressed as the relative Alcian Blue content compared to the NCH conditions at the same time. (B) Calcium deposition was evaluated with Alizarin Red staining. The staining was extracted and quantified, as described in the materials and methods section. Results are expressed as the relative Alizarin Red content compared to the NCH condition at the same time. ${ }^{*} \mathrm{p}<0.05$ compared to the NCH conditions at the same time. (C) Expression of the chondrogenic markers sox 9 , acan, and col2a1 and hypertrophic markers col10a1 and mmp13 was investigated using realtime PCR, as described in the materials and methods section. Results are expressed as relative expression levels compared to NCH. ${ }^{*} \mathrm{p}<0.05$ compared with the NCH conditions. (D) The concentration of MMP13 was measured in the ATDC5 culture supernatant, as described in the materials and methods section. Results are expressed as relative concentrations. ${ }^{*} \mathrm{p}<0.05$ compared with the NCH conditions. 


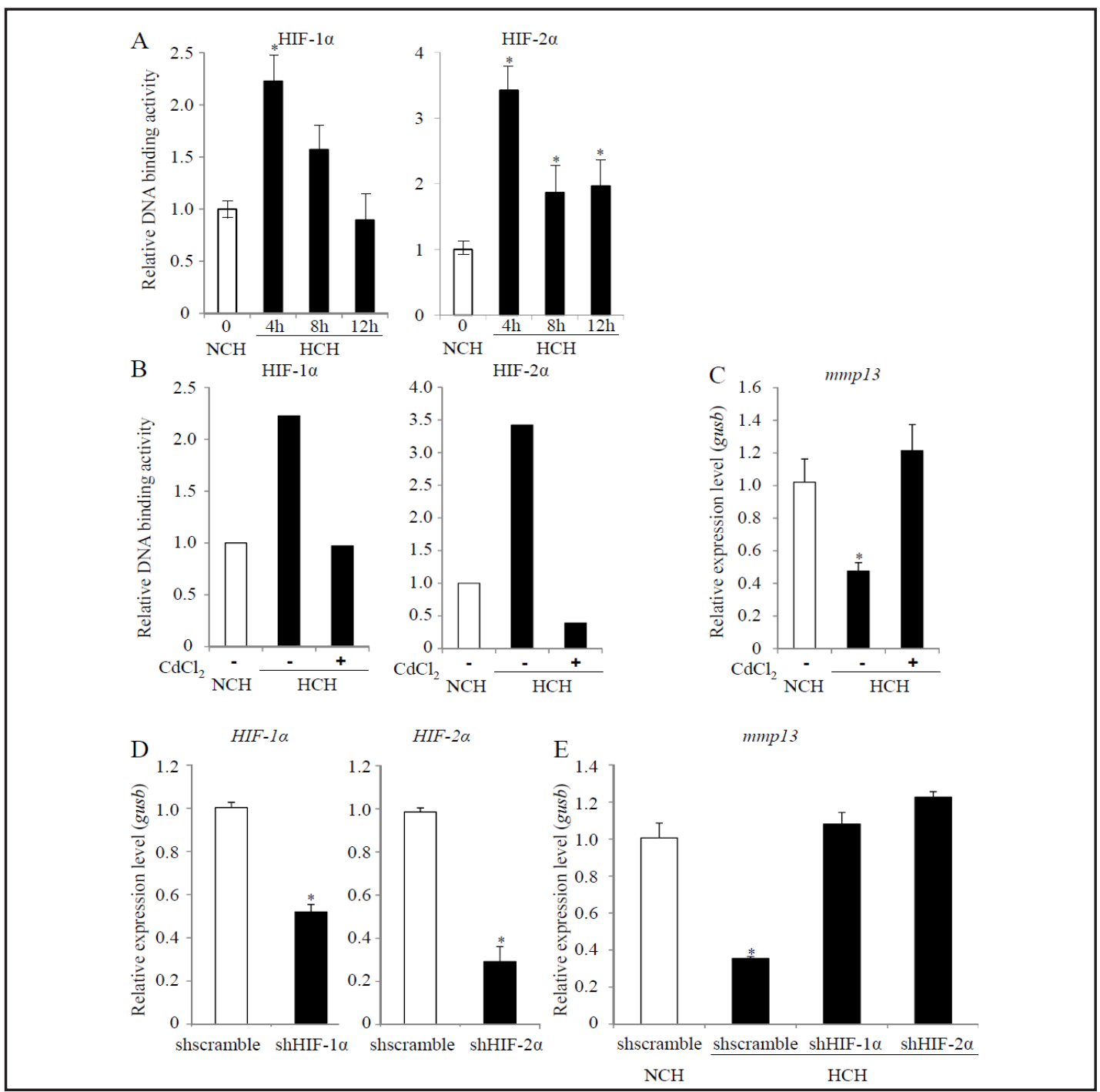

Fig. 5. The role of HIF- $1 \alpha$ and HIF- $2 \alpha$ in the hypoxia-mediated inhibition of hypertrophic differentiation of ATDC5 cells. (A) ATDC5 cells were cultured in the presence of chondrogenic medium for 14 days (NCH / white bars). The cells were then cultured for an additional $4 \mathrm{~h}, 8 \mathrm{~h}$, or $12 \mathrm{~h}$ under hypoxic conditions (HCH / black bars). Nuclear extracts were prepared as described in the materials and methods section, and HIF-1 $\alpha$ and HIF- $2 \alpha$ DNA-binding activity was evaluated with an ELISA-based EMSA using the NoShift Transcription Factor Assay. ${ }^{*} \mathrm{p}<0.05$. (B-C) ATDC5 cells were cultured in the presence of chondrogenic medium for 14 days (NCH / white bars). The cells were then cultured for an additional $24 \mathrm{~h}$ under hypoxic conditions (HCH / black bars) in the presence or absence of cadmium chloride $\left(\mathrm{CdCl}_{2}\right)$. (B) HIF-1 $\alpha$ and HIF-2 $\alpha$ DNA-binding activity was evaluated with an ELISA-based EMSA using the NoShift Transcription Factor Assay. (C) Expression of the hypertrophic marker mmp13 was investigated using real-time PCR, as described in the materials and methods section. Results are expressed as relative expression levels compared to the NCH conditions. ${ }^{*} p<0.05$ compared with the NCH conditions. (D-E) ATDC5 cells were cultured in the presence of chondrogenic medium for 14 days (white bars). The cells were then cultured for an additional $24 \mathrm{~h}$ under hypoxic conditions (black bars) and infected with a lentiviral vector carrying shscramble, shHIF-1 $\alpha$, or shHIF- $2 \alpha$. (D) Expression of hif-1a and epas1 coding for HIF-1 $\alpha$ and HIF- $2 \alpha$, respectively, was investigated using realtime PCR, as described in the materials and methods section. Results are expressed as relative expression levels compared to the NCH conditions. ${ }^{*} \mathrm{p}<0.05$ compared with the NCH conditions. (E) Expression of the hypertrophic marker mmp13 was investigated using real-time PCR, as described in the materials and methods section. Results are expressed as relative expression levels compared to the NCH conditions. ${ }^{*} \mathrm{p}<0.05$ compared with the NCH conditions. 


\section{Discussion}

The control of chondrogenic differentiation of MSC, and notably prevention of their hypertrophic conversion, remains an important challenge for the repair of cartilage towards a non-calcified, hyaline-like tissue. Indeed, this issue is well known with in vitro MSC chondrogenic differentiation, which mimics the successive steps of the development of growth plate chondrocytes and induces the formation of hypertrophic chondrocytes, leading to the calcification of the extracellular matrix. Whilst it is acknowledged that low oxygen tension can stimulate chondrogenic commitment while simultaneously inhibiting osteogenic differentiation of ASC and BM-derived MSC [32, 40], the effect of low oxygen tension on their hypertrophic differentiation had not yet been addressed. Therefore, with a view towards optimizing chondrogenic differentiation of ASC for cartilage repair, we aimed to determine whether low oxygen tension an easy-to-use, tunable, and safe environmental factor could modulate the emergence of early and late chondrogenic differentiation of ASCderived chondrocytes.

We characterized the early chondrogenic and late hypertrophic differentiation of human ASC. Our data demonstrated that ASC that committed towards the chondrogenic lineage concomitantly expressed hyaline (SOX9, ACAN and COL2A1), as well as hypertrophic (COL10A1 and MMP13) cartilaginous markers. This concomitant expression of early and late chondrogenic markers could arise from the heterogeneity of the ASC population, which is likely to lead to variability in the chondrogenic potential of specific cell subclones. Having demonstrated the chondrogenic and hypertrophic differentiation of ASC, we next sought to investigate the effect of low oxygen tension on these phenotypes. Our results confirmed that hypoxia could promote chondrogenic differentiation of ASC, as previously reported [32, 40]. Interestingly, we found that the hypertrophic markers were downregulated under hypoxic conditions compared to normoxic.

To investigate the intracellular mechanism of the hypoxic response, we proceeded with a more accessible, reproducible, homogenous model of chondrogenic cells. Among the relevant reported models for chondrogenic differentiation, ATDC5 cells remain the only cell line that recapitulates, in a temporally-regulated manner, the full range of events described during the differentiation of growth plate chondrocytes [38, 39]. Therefore, ATDC5 cells are an appropriate in vitro model to decipher the role of biological factors that can influence chondrogenesis [41]. Prior to investigating the effects of low oxygen tension on the hypertrophic phenotype of ATDC5 cells, we first monitored the emergence of hypertrophic differentiation over time. In the present study, ATDC5 cells mimicked the major stages of the endochondral differentiation process for chondrocytes, including: (i) early commitment, as evidenced by sox 9 , acan, and col2a1 expression and sulfated GAG and collagen-enriched nodule formation and (ii) terminal conversion towards a hypertrophic phenotype, as evidenced by the increased expression of col10a1 and mmp13 mRNA and the extracellular matrix calcification. Using this ATDC5 cells model for chondrogenesis, the effect of low oxygen tension on hypertrophic differentiation was investigated during day 14 to day 21 of cell culture in chondrogenic medium. We found that hypoxia promoted chondrogenic differentiation of ATDC5 cells, as evidenced by the increased expression of sox9, acan and col2a1 mRNA. The GAG accumulation was not significantly modified by the oxygen tension, but hypoxic conditions decreased the production of a calcified matrix, downregulated the expression of hypertrophic markers (col10a1 and $\mathrm{mmp} 13$ ) and reduced mmp13 release into the extracellular medium. These results demonstrated that hypoxia inhibits the emergence of a hypertrophic phenotype in ATDC5 cells. Altogether, our data strongly suggest that hypoxia can promote and control chondrogenesis in ATDC5 cells by differentially acting on both the early chondrogenic and late hypertrophic phenotypes.

Collectively, our findings in ASC and ATDC5 cells demonstrate that chondrogenic differentiation of human and murine chondrocytes is modulated by low oxygen tension in a comparable manner. In light of these data, it seems reasonable to assume that the hypoxic effects may be mediated through a universal pathway involving common biological effectors. 
Among these biological effectors, HIF- $1 \alpha$ and HIF- $2 \alpha$ are potent intracellular transducers of low oxygen effects [42]. HIF- $1 \alpha$ and HIF- $2 \alpha$ are reported to improve chondrogenesis of cells through induction of collagen II and aggrecan expression. This increased expression is mediated through their interaction with the transcription factor SOX9, which is the main promoter of chondrogenesis $[23,43,44]$. Consistent with these observations, we found that $5 \% \mathrm{O}_{2}$ is sufficient to induce the DNA-binding activity of HIF- $1 \alpha$ and HIF- $2 \alpha$.

Recently, the specific roles of HIF- $1 \alpha$ and HIF- $2 \alpha$ have received considerable attention. In contrast with HIF-1 $\alpha$ [45], the role of HIF- $2 \alpha$ during chondrogenesis is debatable [46]. It has been shown that HIF-2 $\alpha$ can induce the expression of hypertrophic markers such as type X collagen and MMP13 in hypertrophic and osteoarthritic chondrocytes $[47,48]$. These studies suggest that HIF- $1 \alpha$ and HIF- $2 \alpha$ have distinct functions in cartilage tissue. In articular chondrocytes, HIF- $1 \alpha$ promotes homeostatic pathways, whereas HIF- $2 \alpha$ could promotes the degradation pathways that foster osteoarthritis [49]. However, whether HIF- $1 \alpha$ and HIF- $2 \alpha$ may also have distinct roles in controlling the hypoxia-mediated early and late differentiation process of chondrogenic cells remains unknown.

Accordingly, we investigated the functional involvement of HIF- $1 \alpha$ and HIF- $2 \alpha$ in the hypoxia-mediated control of hypertrophic differentiation, using two complementary approaches for HIF inhibition: (i) the use of a broad-range HIF chemical inhibitor, cadmium chloride [50] and (ii) the use of RNA interference with shRNA against HIF- $1 \alpha$ and HIF- $2 \alpha$. Since HIF- $\alpha$ are crucial for cell viability and an adaptive metabolic response to hypoxia [51, 52], we were not surprised to observe cytotoxic effects from both HIF inhibition approaches. Under our experimental conditions, only short-term HIF inhibitor strategies could be applied, and mmp13 was the only hypertrophic marker downregulated. However, further investigation is required to better understand the molecular relationship between the HIF- $\alpha$ pathway and oxygen-dependent regulation of the mmp13 transcript. In addition, it is still unknown whether the HIF- $\alpha$ pathway may also be involved in the regulation of other hypertrophic markers, such as type X collagen. Future studies will require the development of specific, non-cytotoxic molecular tools for these analyses.

Our study demonstrated that low oxygen tension differentially affects the early and late chondrogenic differentiation of two complementary models of chondrogenesis: human ASC and murine ATDC5 cells. A 5\% oxygen tension controls the chondrogenic differentiation of ASC toward a stable non-hypertrophic phenotype and prevents the formation of a mineralized cartilaginous matrix. For cartilage tissue engineering, the control of chondrogenic differentiation of ASC is crucial to promote the formation of a long-term functional cartilage tissue. Collectively, our findings reveal that oxygen tension is an instrumental tool for efficient and reliable MSC-based chondrogenesis. Because hypoxic preconditioning of ASC enhances cartilage-like tissue formation in rabbit articular defects [53], the long-term objective of this study was to prevent the in vivo formation of a calcified matrix from chondrogenicallycommitted MSC through hypoxia-mediated prevention of their hypertrophic differentiation. We still do not know if hypoxic conditions can provide sustained prevention of hypertrophy and maintenance of a stable chondrogenic phenotype in vivo. However, future studies can now address this issue in adapted preclinical animal models of cartilage repair.

\section{Acknowledgments}

This study was financed with grants from the "Fondation Arthritis Courtin", the "Société Française de Rhumatologie", ANR young researchers "Scartifold" project, ANR Tecsan "Chondrograft" project, the "Fondation de l'Avenir pour la Recherche Médicale Appliquée" (ET7-451 and ET9-491), les Haras Nationaux, Graftys S.A., and INSERM U791. C. Merceron and S. Portron received a fellowship from the "Région des Pays de la Loire, Bioregos I and II program". The authors also gratefully acknowledge F. Lejeune (Clinique Bretéché, Nantes, France) for harvesting the human lipoaspirates; P. Galéra (EA 3214, Caen, France) for sharing their nuclear extraction protocol; M. Masson for his collaboration in our real- 
Portron et al.: $\mathrm{O}_{2}$ Tension Regulates Early and Late Chondrogenesis

time PCR experiments; and F. Mazurier for helpful discussions and assistance in the shRNA experiments.

\section{Reference}

1 Peterson L, Vasiliadis HS, Brittberg M, Lindahl A: Autologous chondrocyte implantation: A long-term follow-up. Am J Sports Med 2010;38:1117-1124.

- Vinatier C, Bouffi C, Merceron C, Gordeladze J, Brondello JM, Jorgensen C, Weiss P, Guicheux J, Noel D: Cartilage tissue engineering: Towards a biomaterial-assisted mesenchymal stem cell therapy. Curr Stem Cell Res Ther 2009;4:318-329.

- Vinatier C, Gauthier O, Fatimi A, Merceron C, Masson M, Moreau A, Moreau F, Fellah B, Weiss P, Guicheux $\mathrm{J}$ : An injectable cellulose-based hydrogel for the transfer of autologous nasal chondrocytes in articular cartilage defects. Biotechnol Bioeng 2009;102:1259-1267.

-4 Filardo G, Madry H, Jelic M, Roffi A, Cucchiarini M, Kon E: Mesenchymal stem cells for the treatment of cartilage lesions: From preclinical findings to clinical application in orthopaedics. Knee Surg Sports Traumatol Arthrosc 2013;21:1717-1729.

5 Veronesi F, Giavaresi G, Tschon M, Borsari V, Nicoli Aldini N, Fini M: Clinical use of bone marrow, bone marrow concentrate, and expanded bone marrow mesenchymal stem cells in cartilage disease. Stem Cells Dev 2013;22:181-192.

6 Roelofs AJ, Rocke JP, De Bari C: Cell-based approaches to joint surface repair: A research perspective. Osteoarthritis Cartilage 2013;21:892-900.

7 Gawlitta D, Farrell E, Malda J, Creemers LB, Alblas J, Dhert WJ: Modulating endochondral ossification of multipotent stromal cells for bone regeneration. Tissue Eng Part B Rev 2010;16:385-395.

-8 Kronenberg HM: Developmental regulation of the growth plate. Nature 2003;423:332-336.

-9 Barry F, Boynton RE, Liu B, Murphy JM: Chondrogenic differentiation of mesenchymal stem cells from bone marrow: Differentiation-dependent gene expression of matrix components. Exp Cell Res 2001;268:189200.

10 Coleman CM, Vaughan EE, Browe DC, Mooney E, Howard L, Barry F: Growth differentiation factor-5 enhances in vitro mesenchymal stromal cell chondrogenesis and hypertrophy. Stem Cells Dev 2013;22:1968-1976.

-11 Ichinose S, Tagami M, Muneta T, Sekiya I: Morphological examination during in vitro cartilage formation by human mesenchymal stem cells. Cell Tissue Res 2005;322:217-226.

12 Lee JM, Im GI: Pthrp isoforms have differing effect on chondrogenic differentiation and hypertrophy of mesenchymal stem cells. Biochem Biophys Res Commun 2012;421:819-824.

13 Mueller MB, Fischer M, Zellner J, Berner A, Dienstknecht T, Prantl L, Kujat R, Nerlich M, Tuan RS, Angele P: Hypertrophy in mesenchymal stem cell chondrogenesis: Effect of tgf-beta isoforms and chondrogenic conditioning. Cells Tissues Organs 2010;192:158-166.

$\checkmark 14$ Mueller MB, Tuan RS: Functional characterization of hypertrophy in chondrogenesis of human mesenchymal stem cells. Arthritis Rheum 2008;58:1377-1388.

15 Steinert AF, Proffen B, Kunz M, Hendrich C, Ghivizzani SC, Noth U, Rethwilm A, Eulert J, Evans CH: Hypertrophy is induced during the in vitro chondrogenic differentiation of human mesenchymal stem cells by bone morphogenetic protein- 2 and bone morphogenetic protein-4 gene transfer. Arthritis Res Ther 2009;11:R148.

16 Dickhut A, Pelttari K, Janicki P, Wagner W, Eckstein V, Egermann M, Richter W: Calcification or dedifferentiation: Requirement to lock mesenchymal stem cells in a desired differentiation stage. J Cell Physiol 2009;219:219-226.

-17 Pelttari K, Winter A, Steck E, Goetzke K, Hennig T, Ochs BG, Aigner T, Richter W: Premature induction of hypertrophy during in vitro chondrogenesis of human mesenchymal stem cells correlates with calcification and vascular invasion after ectopic transplantation in scid mice. Arthritis Rheum 2006;54:3254-3266.

18 Haselgrove JC, Shapiro IM, Silverton SF: Computer modeling of the oxygen supply and demand of cells of the avian growth cartilage. Am J Physiol 1993;265:C497-506.

19 Silver IA: Measurement of ph and ionic composition of pericellular sites. Philos Trans R Soc Lond B Biol Sci 1975;271:261-272. 
Portron et al.: $\mathrm{O}_{2}$ Tension Regulates Early and Late Chondrogenesis

20 Zhou S, Cui Z, Urban JP: Factors influencing the oxygen concentration gradient from the synovial surface of articular cartilage to the cartilage-bone interface: A modeling study. Arthritis Rheum 2004;50:3915-3924.

21 Meretoja VV, Dahlin RL, Wright S, Kasper FK, Mikos AG: The effect of hypoxia on the chondrogenic differentiation of co-cultured articular chondrocytes and mesenchymal stem cells in scaffolds. Biomaterials 2013;34:4266-4273.

22 Sheehy EJ, Buckley CT, Kelly DJ: Oxygen tension regulates the osteogenic, chondrogenic and endochondral phenotype of bone marrow derived mesenchymal stem cells. Biochem Biophys Res Commun 2012;417:305-310.

23 Amarilio R, Viukov SV, Sharir A, Eshkar-Oren I, Johnson RS, Zelzer E: Hif1alpha regulation of sox9 is necessary to maintain differentiation of hypoxic prechondrogenic cells during early skeletogenesis. Development 2007;134:3917-3928.

24 Gawlitta D, van Rijen MH, Schrijver EJ, Alblas J, Dhert WJ: Hypoxia impedes hypertrophic chondrogenesis of human multipotent stromal cells. Tissue Eng Part A 2012;18:1957-1966.

25 Hirao M, Tamai N, Tsumaki N, Yoshikawa H, Myoui A: Oxygen tension regulates chondrocyte differentiation and function during endochondral ossification. J Biol Chem 2006;281:31079-31092.

26 Pittenger MF, Mackay AM, Beck SC, Jaiswal RK, Douglas R, Mosca JD, Moorman MA, Simonetti DW, Craig S, Marshak DR: Multilineage potential of adult human mesenchymal stem cells. Science 1999;284:143-147.

27 Strioga M, Viswanathan S, Darinskas A, Slaby 0, Michalek J: Same or not the same? Comparison of adipose tissue-derived versus bone marrow-derived mesenchymal stem and stromal cells. Stem Cells Dev 2012;21:2724-2752.

28 Zuk PA, Zhu M, Ashjian P, De Ugarte DA, Huang JI, Mizuno H, Alfonso ZC, Fraser JK, Benhaim P, Hedrick MH: Human adipose tissue is a source of multipotent stem cells. Mol Biol Cell 2002;13:4279-4295.

-29 Hennig T, Lorenz H, Thiel A, Goetzke K, Dickhut A, Geiger F, Richter W: Reduced chondrogenic potential of adipose tissue derived stromal cells correlates with an altered tgfbeta receptor and bmp profile and is overcome by bmp-6. J Cell Physiol 2007;211:682-691.

-30 Kim HJ, Im GI: The effects of erk1/2 inhibitor on the chondrogenesis of bone marrow- and adipose tissuederived multipotent mesenchymal stromal cells. Tissue Eng Part A 2009;16:851-860.

31 Mehlhorn AT, Niemeyer P, Kaschte K, Muller L, Finkenzeller G, Hartl D, Sudkamp NP, Schmal H: Differential effects of bmp-2 and tgf-beta1 on chondrogenic differentiation of adipose derived stem cells. Cell Prolif 2007;40:809-823.

32 Merceron C, Portron S, Masson M, Fellah BH, Gauthier O, Lesoeur J, Cherel Y, Weiss P, Guicheux J, Vinatier C: Cartilage tissue engineering: From hydrogel to mesenchymal stem cells. Biomed Mater Eng 2010;20:159166.

-33 Geronimi F, Richard E, Lamrissi-Garcia I, Lalanne M, Ged C, Redonnet-Vernhet I, Moreau-Gaudry F, de Verneuil H: Lentivirus-mediated gene transfer of uroporphyrinogen iii synthase fully corrects the porphyric phenotype in human cells. J Mol Med (Berl) 2003;81:310-320.

34 Merceron C, Portron S, Vignes-Colombeix C, Rederstorff E, Masson M, Lesoeur J, Sourice S, Sinquin C, Colliec-Jouault S, Weiss P, Vinatier C, Guicheux J: Pharmacological modulation of human mesenchymal stem cell chondrogenesis by a chemically oversulfated polysaccharide of marine origin: Potential application to cartilage regenerative medicine. Stem Cells 2012;30:471-480.

-35 Duval E, Leclercq S, Elissalde JM, Demoor M, Galera P, Boumediene K: Hypoxia-inducible factor 1alpha inhibits the fibroblast-like markers type i and type iii collagen during hypoxia-induced chondrocyte redifferentiation: Hypoxia not only induces type ii collagen and aggrecan, but it also inhibits type i and type iii collagen in the hypoxia-inducible factor 1alpha-dependent redifferentiation of chondrocytes. Arthritis Rheum 2009;60:3038-3048.

-36 Magne D, Bluteau G, Lopez-Cazaux S, Weiss P, Pilet P, Ritchie HH, Daculsi G, Guicheux J: Development of an odontoblast in vitro model to study dentin mineralization. Connect Tissue Res 2004;45:101-108.

-37 Andriamanalijaona R, Felisaz N, Kim SJ, King-Jones K, Lehmann M, Pujol JP, Boumediene K: Mediation of interleukin-1beta-induced transforming growth factor beta1 expression by activator protein 4 transcription factor in primary cultures of bovine articular chondrocytes: Possible cooperation with activator protein 1. Arthritis Rheum 2003;48:1569-1581.

-38 Atsumi T, Miwa Y, Kimata K, Ikawa Y: A chondrogenic cell line derived from a differentiating culture of at805 teratocarcinoma cells. Cell Differ Dev 1990;30:109-116. 


\begin{tabular}{|c|c|c|}
\hline Cellular Physiology & Cell Physiol Biochem 2015;35:841-857 & \\
\hline and Biochemistry & $\begin{array}{l}\text { DOI: } 10.1159 / 000369742 \\
\text { Published onIIne: January } 30,2015\end{array}$ & $\begin{array}{l}\text { O } 2015 \text { S. Karger AG, Basel } \\
\text { www.karger.com/cpb }\end{array}$ \\
\hline
\end{tabular}

-39 Shukunami C, Ishizeki K, Atsumi T, Ohta Y, Suzuki F, Hiraki Y: Cellular hypertrophy and calcification of embryonal carcinoma-derived chondrogenic cell line atdc5 in vitro. J Bone Miner Res 1997;12:1174-1188.

40 Markway BD, Tan GK, Brooke G, Hudson JE, Cooper-White JJ, Doran MR: Enhanced chondrogenic differentiation of human bone marrow-derived mesenchymal stem cells in low oxygen environment micropellet cultures. Cell Transplant 2010;19:29-42.

-41 Magne D, Bluteau G, Faucheux C, Palmer G, Vignes-Colombeix C, Pilet P, Rouillon T, Caverzasio J, Weiss P, Daculsi G, Guicheux J: Phosphate is a specific signal for atdc5 chondrocyte maturation and apoptosisassociated mineralization: Possible implication of apoptosis in the regulation of endochondral ossification. J Bone Miner Res 2003;18:1430-1442.

42 Semenza GL: Regulation of oxygen homeostasis by hypoxia-inducible factor 1. Physiology (Bethesda) 2009;24:97-106.

43 Lafont JE, Talma S, Hopfgarten C, Murphy CL: Hypoxia promotes the differentiated human articular chondrocyte phenotype through sox9-dependent and -independent pathways. J Biol Chem 2008;283:47784786.

44 Robins JC, Akeno N, Mukherjee A, Dalal RR, Aronow BJ, Koopman P, Clemens TL: Hypoxia induces chondrocyte-specific gene expression in mesenchymal cells in association with transcriptional activation of sox9. Bone 2005;37:313-322.

45 Duval E, Bauge C, Andriamanalijaona R, Benateau H, Leclercq S, Dutoit S, Poulain L, Galera P, Boumediene $\mathrm{K}$ : Molecular mechanism of hypoxia-induced chondrogenesis and its application in in vivo cartilage tissue engineering. Biomaterials 2012;33:6042-6051.

46 Murphy CL: Hif-2alpha--a mediator of osteoarthritis? Cell Res 2010;20:977-979.

47 Saito T, Fukai A, Mabuchi A, Ikeda T, Yano F, Ohba S, Nishida N, Akune T, Yoshimura N, Nakagawa T, Nakamura K, Tokunaga K, Chung UI, Kawaguchi H: Transcriptional regulation of endochondral ossification by hif-2alpha during skeletal growth and osteoarthritis development. Nat Med 2010;16:678-686.

-48 Yang S, Kim J, Ryu JH, Oh H, Chun CH, Kim BJ, Min BH, Chun JS: Hypoxia-inducible factor-2alpha is a catabolic regulator of osteoarthritic cartilage destruction. Nat Med 2011;16:687-693.

49 Husa M, Liu-Bryan R, Terkeltaub R: Shifting hifs in osteoarthritis. Nat Med 2011;16:641-644.

50 Chun YS, Choi E, Kim GT, Choi H, Kim CH, Lee MJ, Kim MS, Park JW: Cadmium blocks hypoxia-inducible factor (hif)-1-mediated response to hypoxia by stimulating the proteasome-dependent degradation of hif1alpha. Eur J Biochem 2000;267:4198-4204.

51 Maes C, Carmeliet G, Schipani E: Hypoxia-driven pathways in bone development, regeneration and disease. Nat Rev Rheumatol 2012;8:358-366.

-52 Zhang H, Bosch-Marce M, Shimoda LA, Tan YS, Baek JH, Wesley JB, Gonzalez FJ, Semenza GL: Mitochondrial autophagy is an hif-1-dependent adaptive metabolic response to hypoxia. J Biol Chem 2008;283:1089210903.

53 Portron S, Merceron C, Gauthier O, Lesoeur J, Sourice S, Masson M, Fellah BH, Geffroy O, Lallemand E, Weiss P, Guicheux J, Vinatier C: Effects of in vitro low oxygen tension preconditioning of adipose stromal cells on their in vivo chondrogenic potential: Application in cartilage tissue repair. PLoS One 2013;8:e62368. 